Prace Komisji Geografii Komunikacji PTG Transport Geography Papers of Polis

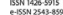
$21(4) / 2018$

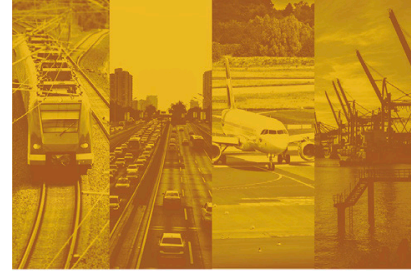

\section{Transport Geography Papers of Polish Geographical Society}

2018, 21(4), 20-29

DOI 10.4467/2543859XPKG.18.022.10780

\title{
TRANSPORT AND GEOGRAPHICAL POSITION OF LENINGRAD - ST. PETERSBURG IN THE PASSENGER TRANSPORTATION SYSTEM
}

\section{Położenie komunikacyjne i geograficzne Leningradu - St. Petersburga w systemach transportu pasażerskiego}

\author{
Vasilii Martynov (1), Yuri Sherstobitov (2) \\ (1) Faculty of Geography, Department of Economic Geography, Herzen State Pedagogical University of Russia, Moika River Embankment 48, 191186 St. Petersburg, \\ Russia \\ E-mail: martin-vas@yandex.ru (corresponding author) \\ (2) Faculty of Geography, Department of Economic Geography, Herzen State Pedagogical University of Russia, Moika River Embankment 48, 191186 St. Petersburg, \\ Russia \\ E-mail: sherstobitoff@mail.ru
}

\section{Citation:}

Martynov V., Sherstobitov Y., 2018, Transport and geographical position of Leningrad - St. Petersburg in the passenger transportation system, Prace Komisji Geografii Komunikacji PTG, 21(4), 20-29.

\begin{abstract}
The article deals with the geographic and transport position that Leningrad - St. Petersburg takes in the passenger transportation system, which differs to a great extent from its position in the system of freight transportation and undergoes considerable changes with time. The time period under analysis is from the 1950 s to the 1960 s and to the present moment. The transformation of Leningrad - St. Petersburg position in the system of airline passenger transportation is studied by means of 1) the coefficient of transportation connectivity method (the CTC method) developed by the author of the article and 2) passenger transportation zoning covering those territories which are connected with the city by airline and railway transportation facilities. The greatest attention is paid to the transportation zoning of the former Soviet Union, and this let us to rely on the obtained data in studying other cities' airline connections through the coefficient of transportation connectivity method. The undertaken comparing of passenger airline destinations through decades shows which transportation destinations ensured the maximum growth in passenger transportation in Leningrad - St. Petersburg in the late 1980s and which ones provided for the sharp decline or decrease in the 1990s. It can also be noted that Pulkovo airport passenger transportation is currently increasing mostly due to the western destinations than the eastern ones.
\end{abstract}

Keywords: transport geography, air transport, railway transport, passenger transport, Sankt Petersburg 


\section{Introduction}

Transport geography is the direction of social and economic geography which has been actively developed for the last hundred years. It is possible to allocate two main directions of researches in the field of geography of transport: "geography of lines" and "geography of communication". "The geography of lines" pays the most attention to the development of transport communications, its technical and topological characteristics. "The geography of communication" investigates mainly transportations which are made on these routes. "The geography of lines" is identical to turnpike freight and passenger traffic - automobile and trucks go on the same highways, cargo and passenger trains in most cases move by the same railroads, cargo and passenger aircrafts use the same airports. But the logic of freight and passenger traffics is absolutely different. Freight traffic is supported mainly for economic reasons, i.e. the more profit which can be received as a result of movement of freight, the better. In case of passenger service economic interests can be present as well, but also social and political goals are of great importance. Respectively the transport and geographic position in the system of freight and passenger traffic can be absolutely different.

"The transport and geographic position" (TGP) is one of key concepts of geography of transport. The outstanding Soviet geographer N.N. Baransky wrote that the position of a geographical object in relation to transport routes is most often considered and therefore the term "transport position" in spite of the fact that it is narrower, is often used instead of the term "economic and geographical position". S.A. Tarkhov gave the following definition: "Transport and geographical position of the settlement, city agglomeration, region and other geographical objects in relation to transport network, network of transport hubs and streams". As L.A. Bezrukov and Ts.B. Dashpilov note: "... despite the better state of exploration of TGP in comparison with other types of EGP, effort on its quantitative assessment still hasn't brought desirable results". Many researchers who tried to express TGP in the quantitative indices used only one topological component, for example, A.G. Topichev applied only an indicator of compendency which was insufficient, as synthesis of connectivity and remoteness was necessary. Other researchers placed emphasis only on such indicators as time and distance.

V.N. Bugromenko in a number of researches calculated the level of integrated transport availability (calculation of availability of clusters in relation to all network) where the remoteness, connectivity and other topological characteristics of some regions of the country were considered, but passenger traffics weren't considered and, in general, only "the cost of movements" was estimated. S.A. Tarkhov analysed changes of spatial structure of air transportation in the 1990s-2000s; topological methods, data on passenger traffics and the difference of number of air communications were taken as a basis.

\section{Research methodology}

TGP of settlements in terms of freight and passenger traffic often differs strongly. One of the largest cities of Russia where such distinctions are most brightly traced is Leningrad - St. Petersburg. For freight transportation it is the transport hub as exactly there is a mass transfer of freights between different types of transport (since the 19th century a huge part was played by shipping, after the October revolution a basis of a system of transport economic relations of the city were the railroads). For passenger traffic the city is the deadlock as the size of transit passenger streams is extremely small. As for the air transportation, they are measured by percent units, on railway transport through Ladozhsky railway station in transit pass only passengers of the trains going from the North of the European part of Russia. In turn, for the last decades the position of St. Petersburg in the system of passenger transport communications has also been modified.

It is offered to estimate TGP of a settlement by means of an author's method of coefficient of transport compendency (further $-\mathrm{C}_{\mathrm{TC}}$ ) which has to demonstrate how close the communications of the city with various transport areas are. For the sake of simplification of the assessment the division into districts of territories with which the city (in this case St. Petersburg) is connected by passenger traffic was carried out. When carrying out division into districts of Russia the author was guided by the scheme of division of the country into economic makroregions by professor V.K. Bugaev (2007) as it is more suitable than a grid of federal districts and economic region of the former State Planning Committee and most fully meets the purposes of transport geographical zoning of the country. Modification of certain sites was carried out and several new areas were allocated. The transport division into districts presented in fig. 1 allows to be based on while carrying out researches of passenger communications of other cities of Russia by means of a method of calculation of coefficient of transport compendency $\left(\mathrm{C}_{\mathrm{TC}}\right)$. 


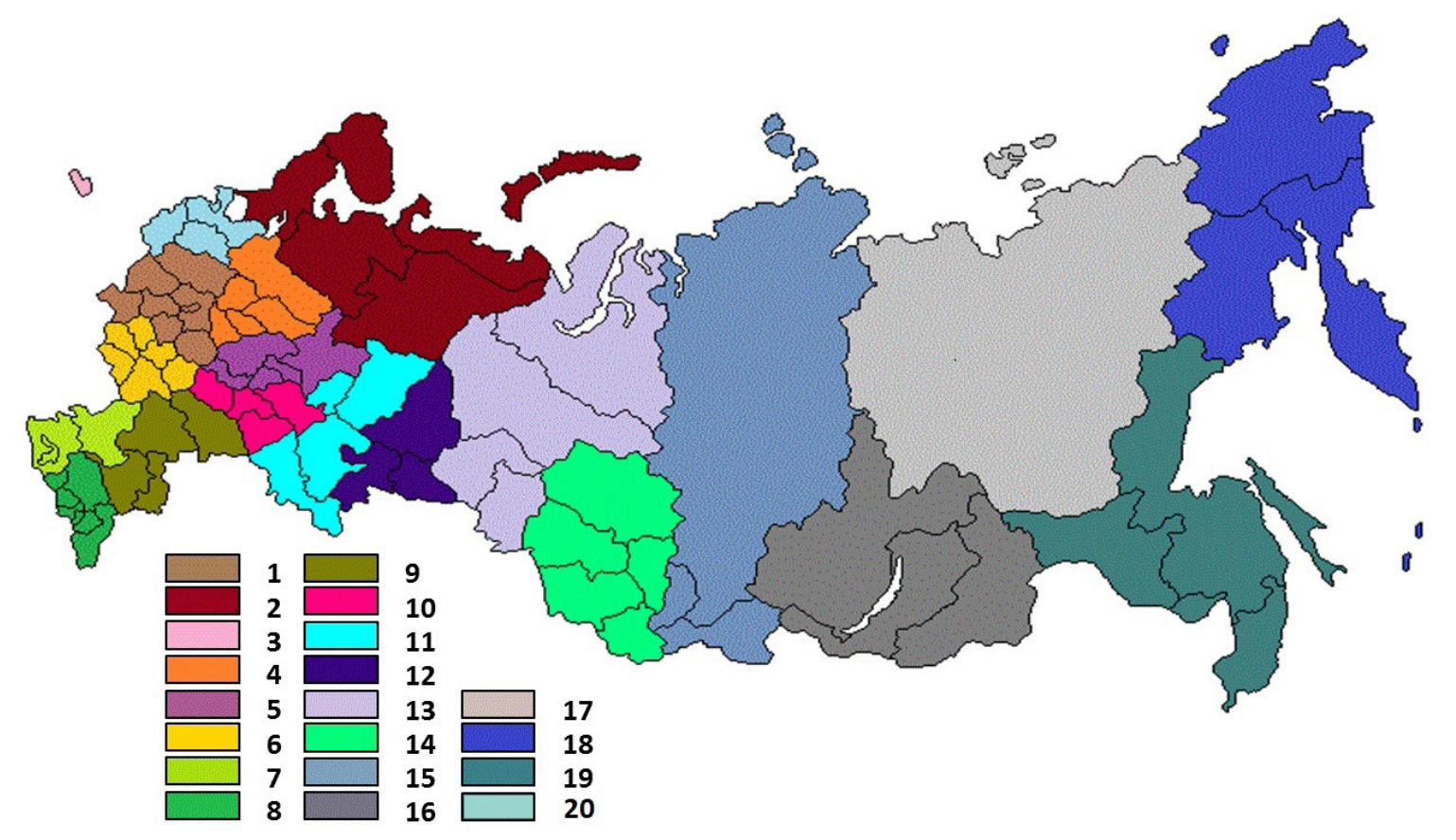

Fig. 1. Transport and geographical regions of Russia:

1 - Central, 2 - Northern, 3 - Kaliningradsky, 4 - Verhnevolzhsky, 5 - Volgo-Vyatsky, 6 - Central Chernozem, 7 - AzovoChernomorsky, 8 - North Caucasian, 9 - Lower Volga, 10 - Middle Volga, 11 - West Ural, 12 - East Ural, 13 - West Siberian, 14 - Kuznetsko-Altaisky, 15 - Yeniseisky, 16 - Baikal, 17 - Yakutsky, 18 - the North of the Far East, 19 - the South of the Far East, 20 - North-West (including St. Petersburg).

Source: own elaboration.

The territory of Russia was divided by us into nineteen transport areas; the territory of the former USSR was divided into ten areas. To one area the former Transcaucasian and Baltic republics close to each other (on three in the transport area), the Central Asian republics are collected (on two). Separately Belarus, Kazakhstan and Moldova are considered. The territory of the Ukraine is divided in the transport plan for the western and east part: so, the Chernihiv, Kiev and Vinnytsia regions are included into the western area, and Sumy, Poltava, Cherkasy and Odessa - in east (the territory of the Crimea is considered separately). Foreign Europe was divided into four areas. The Northern area includes all Scandinavian countries, the Eastern comprises the countries of the former East block, except the territory of the GDR, the Southern area includes the countries on the coast of the Mediterranean Sea. All other countries from Austria and Germany in the east, to Ireland and Great Britain in the West are included into the western part. The rest of the world was considered as one area as the main passenger transport communications of St. Petersburg - Leningrad generally provide its communication with the remaining territory of Russia, the former republics of the USSR and foreign Europe.
The authors suggest using the coefficient of transport compendency $\left(C_{T C}\right)$ calculated as follows:

$$
C_{\mathrm{TC}}=\Sigma\left(C_{1}+C_{2}+\ldots C_{n}\right)
$$

where $C_{\mathrm{TC}}$ - stands for the coefficient of transport compendency (with a certain area);

\section{$C_{1} \ldots C_{n}$ are private coefficients of a separate flight, the train (the hook-on car).}

For forming of $\mathrm{C}_{\mathrm{TC}}$ tab. 1 and 2 in which private coefficients are specified were made. From these tables it is visible that the decisive factor influencing $C_{T C}$ is the frequency of running of the train and flights of a certain run. The second factor is seasonality, the third is whether the train (or airplane) is transit for the area or it carries out in it a final stop (landing). The railway coefficient is also influenced by communication type - by means of the full-fledged train or the through-car. Daily frequency of running of one year-round flight or the train is taken by us for unit. The private coefficient of transit routes is calculated by division into two: so, at the year-round daily train "Arktika" Murmansk-St.Petersburg-Moscow it is equal to 0.5 . 
Tab. 1. Private railway coefficients

\begin{tabular}{|c|c|c|c|c|c|}
\hline $\begin{array}{c}\text { Frequency } \\
\text { of running of trains } \\
\text { (days a week) }\end{array}$ & $\begin{array}{c}\text { Year-round } \\
\text { trains }\end{array}$ & $\begin{array}{c}\text { Seasonal } \\
\text { trains }\end{array}$ & $\begin{array}{c}\text { Hook-on cars/ } \\
\text { trains that are } \\
\text { transit for areas }\end{array}$ & $\begin{array}{c}\text { Hook-on cars and seasonal } \\
\text { trains, transit for areas, / } \\
\text { hook-on cars (seasonal) }\end{array}$ & $\begin{array}{c}\text { Hook-on cars, } \\
\text { transit for areas, } \\
\text { (seasonal) }\end{array}$ \\
\hline 7 days & 1 & 0.5 & 0.4 & 0.2 & 0.1 \\
\hline 6 days & 0.9 & 0.4 & 0.4 & 0.2 & 0.1 \\
\hline 5 days & 0.8 & 0.3 & 0.4 & 0.1 & 0.1 \\
\hline 4 days & 0.6 & 0.2 & 0.3 & 0.1 & 0.05 \\
\hline 3 days & 0.4 & 0.2 & 0.3 & 0.1 & 0.05 \\
\hline 2 days & 0.3 & 0.1 & 0.2 & 0.05 & 0.01 \\
\hline 1 day & 0.2 & 0.05 & 0.1 & 0.1 & 0.05 \\
\hline Even / odd days \\
of running
\end{tabular}

Source: own elaboration.

For example, in 1991 with the Lower Volga transport district Leningrad connected the daily train from/to Volgograd - $C_{1}=1$ and the train from/to Astrakhan plying on odd days $-C_{2}=0.5$. In transit through Saratov and Astrakhan there passed the summer train plying three times a week train from/ to Baku No. 549/550 from $K_{3}=0.1$. Therefore, the indicator of railway communication with the area in 1991 is equal to 1.6 that makes $1.3 \%$ of the general coefficient in a year (122.6). Thus, the sum of $C_{T C}$ of all areas is the general coefficient $\left(C_{g}\right)$ showing changes of value of the settlement in the system of passenger traffic of various types for a certain time period. Water transport is not considered, as sea and river passenger transportations are used exclusively for tourist purposes, and bus transport basically connects Leningrad-St. Petersburg with neighbouring cities and regions.

Tab. 2. Private aviation coefficients

\begin{tabular}{|c|c|c|c|c|}
\hline $\begin{array}{l}\text { Frequency of flights } \\
\text { (days a week) }\end{array}$ & $\begin{array}{l}\text { Year-round } \\
\text { flights }\end{array}$ & $\begin{array}{l}\text { Seasonal } \\
\text { flights }\end{array}$ & $\begin{array}{l}\text { Flights making } \\
\text { intermediate stop }\end{array}$ & $\begin{array}{l}\text { Seasonal flights mak- } \\
\text { ing intermediate stop }\end{array}$ \\
\hline 7 days & 1 & 0.5 & 0.4 & 0.2 \\
\hline 6 days & 0.9 & 0.4 & 0.4 & 0.2 \\
\hline 5 days & 0.8 & 0.3 & 0.4 & 0.2 \\
\hline 4 days & 0.6 & 0.2 & 0.3 & 0.1 \\
\hline 3 days & 0.4 & 0.2 & 0.3 & 0.1 \\
\hline 2 days & 0.3 & 0.1 & 0.2 & 0.1 \\
\hline 1 day & 0.2 & 0.05 & 0.1 & 0.05 \\
\hline $\begin{array}{l}\text { Even / odd days of } \\
\text { running }\end{array}$ & 0.5 & 0.2 & 0.3 & 0.1 \\
\hline $\begin{array}{l}\text { For the purpose } \\
\text { intended }\end{array}$ & 0.1 & \multicolumn{2}{|c|}{0,05} & 0.01 \\
\hline
\end{tabular}

Source: own elaboration. 


\section{Results and their discussion}

Regular air communications (transformation of aviation and railway coefficient is presented in table 3) of Leningrad with the regions of the country started being carried out from the moment of post-war restoration of Shosseynaya airfield, in 1973 the airport got the name "Pulkovo". As of 1965 the leading role in formation of in-Russian communications of the Leningrad airport in Pulkovo was played by the communication with the European North and the Center, $\mathrm{C}_{\mathrm{TC}}$ of communication with which being equal to 7.85 (a share from $C_{g}-14.7 \%$ ) and $5.6(10.5 \%)$ respectively. The share of the majority of regions of the European part of RSFSR was about $1-2 \%$. The Middle Volga and Volga-Vyatka districts boast as at the airports of Kuibyshev, Kazan and Gorky planes from Leningrad carried out intermediate landings. High rate of $C_{\mathrm{TC}}$ (1.6) was characteristic of the densely populated Azovo-Chernomorsky district. The airports of the East Ural district $\left(C_{\mathrm{TC}}=2.9\right)$ besides reception of several regular flights, were used for refueling and landing of passengers in the planes connecting Leningrad with Central Asia and the Far East. The Far East flights provided the high level of the message and with Novosibirsk. In view of mass commissioning of new types of long-haul airliners and lack of through traffic, $C_{\mathrm{TC}}$ Baikal (1.7) and the Southern Far East (2.8) districts surpassed the majority of indicators of the allocated units of the European part of RSFSR. Not covered with the Leningrad air communications there was Upper Volga district that is explained by its neighborhood to the airport capital terminals and the prevalence of railway communication. Towards the middle of the 1960th the through-message with the North of the Far East had not been issued. Within 25 years of the Soviet period the greatest number of units of aviation $\mathrm{C}_{\mathrm{TC}}$ was added by Northern, Azovo-Chernomorsky, West Ural, Middle Volga and West Siberian districts.

By the time of the collapse of the USSR there was a shift of the Leningrad communications towards the European North which share exceeded $17 \%\left(C_{T C}\right.$ in 1991 - 24.75). Communication indicators with the Northern district considerably surpassed the similar values of other units as the Pulkovo Airport was important transit point for planes from Murmansk and Arkhangelsk. The role of the Center $\left(C_{\mathrm{TC}}=8.9\right)$ and short-range communications decreased, $C_{T C}$ of the Azovo-Chernomorsky area considerably raised (up to 6.3). Indicators of other Russian district, to Yenisei in the east, were leveled, being in limits of $2-4 \%$ from $\mathrm{C}_{\mathrm{g}}$. The share of the Yenisei district slightly grew, the message with Yakutia and the North of the Far East appeared. However, the specific weight of Baikal and Southern Far East district fell; having decreased most considerably by the latter - from $5.3 \%$ in 1965 to $1.8 \%$ in 1991. In four Post-Soviet years the structure of internal air communications was reversed. The share of the Center increased in more than four times, communications with the European North most degraded $\left(C_{T C}\right.$ was reduced to 5.6). Short-range lines stopped functioning, the message with Central Chernozem, Middle Volga, North Caucasian, Volga-Vyatka districts worsened [13]. The share of the areas which are to the east of Western Siberia did not exceed 1-2\%.

Tab. 3. Transformation of level of connectivity of Leningrad - St. Petersburg with areas (in terms of CTC)

\begin{tabular}{|c|c|c|c|c|c|c|c|c|c|c|}
\hline \multirow[t]{2}{*}{ District } & 1965 & 1975 & 1991 & 1995 & 2016 & 1965 & 1975 & 1991 & 1995 & 2016 \\
\hline & \multicolumn{5}{|c|}{ Air coefficients } & \multicolumn{5}{|c|}{ Railway coefficients } \\
\hline North-west (junction traffic) & 1 & 2.7 & 1 & - & 0.2 & 2 & 3.8 & 5.6 & 11.7 & 3.1 \\
\hline Central & 5.6 & 14.3 & 8.9 & 11.9 & 42.8 & 14.7 & 22.8 & 26.9 & 23.97 & 34.62 \\
\hline Northern & 7.85 & 17.1 & 24.75 & 5.6 & 15.45 & 10.32 & 9.45 & 15.4 & 15.35 & 11.32 \\
\hline Kaliningradsky & 1 & 1.4 & 1.5 & 0.7 & 5.3 & 1 & 1 & 1 & 0.5 & 0.4 \\
\hline Verhnevolzhsky & - & - & 0.1 & - & 1.4 & 2.01 & 3.65 & 4.4 & 4.1 & 3.5 \\
\hline Volgo-Vyatsky & 1.5 & 2.7 & 3.2 & 0.8 & 2.4 & 2.01 & 2.15 & 3.5 & 3.85 & 4.9 \\
\hline Central Chernozem & 0.8 & 2.4 & 3.05 & 0.5 & 2.2 & 2.2 & 4.15 & 6.05 & 4.62 & 4.5 \\
\hline Azovo-Chernomorsky & 1.6 & 6.6 & 6.3 & 2.5 & 8.5 & 2.3 & 5 & 5.55 & 3.5 & 5 \\
\hline North Caucasian & 0.6 & 3.4 & 3.9 & 1.1 & 3.3 & 1 & 2.4 & 2 & 1.15 & 1.5 \\
\hline Lower Volga & 0.6 & 1.3 & 3.7 & 0.7 & 1.1 & - & 0.25 & 1.6 & 1.3 & 1.5 \\
\hline Middle Volga & 1.8 & 5.1 & 5.4 & 2.5 & 6.2 & - & 0.35 & 0.9 & 1.35 & 2.5 \\
\hline West Ural & 0.7 & 3.1 & 4.8 & 1.7 & 5.1 & 1.01 & 1.35 & 2 & 2.45 & 3.65 \\
\hline East Ural & 2.9 & 6 & 3.8 & 1.6 & 5.2 & 2.05 & 2.15 & 2.4 & 2.8 & 2.75 \\
\hline
\end{tabular}




\begin{tabular}{|c|c|c|c|c|c|c|c|c|c|c|}
\hline West Siberian & 0.2 & 1.7 & 3.7 & 1.8 & 5.1 & 0.2 & 0.1 & 0.2 & 0.4 & 1.5 \\
\hline Kuznetsko-Altaisky & 1.1 & 2.6 & 3.1 & 0.8 & 4.15 & 0.5 & 0.1 & 0.2 & 0.8 & 0.8 \\
\hline Yeniseisky & 0.5 & 2 & 1.6 & 0.8 & 1.3 & - & 0.1 & 0.2 & - & - \\
\hline Baikal & 1.7 & 2.6 & 2 & 0.6 & 0.85 & - & 0.2 & 0.3 & - & - \\
\hline Yakut & - & 0.4 & 0.5 & 0.4 & 0.5 & - & - & - & - & - \\
\hline North of the Far East & - & 1.4 & 1.3 & 0.5 & 0.15 & - & - & - & - & - \\
\hline South of the Far East & 2.8 & 3.7 & 2.2 & 0.9 & 0.9 & - & - & - & - & - \\
\hline Crimean & 0.6 & 4 & 2.2 & 0.4 & 4.35 & 1.6 & 3.35 & 3.5 & 1.35 & - \\
\hline Belarusian & 2.1 & 7.8 & 2.7 & 0.1 & 4 & 5.7 & 7.15 & 8.6 & 7.35 & 5.7 \\
\hline East Ukrainian & 2.55 & 11 & 12.3 & 0.3 & - & 4.5 & 9.75 & 9.6 & 4.5 & 1.4 \\
\hline West Ukrainian & 2.9 & 6.5 & 6.1 & 0.9 & - & 4.2 & 4.8 & 6.5 & 6.65 & 0.8 \\
\hline Moldavian & 0.4 & 1 & 1.3 & 0.5 & 1.4 & - & 1.2 & 1 & 1 & 0.5 \\
\hline Kazakhstan & 1 & 3.5 & 4.7 & 1.6 & 2.9 & 0.2 & 0.3 & 0.7 & 0.9 & 0.3 \\
\hline Kyrgyz-Tajik & - & 1.8 & 2.3 & 0.4 & 2.6 & - & - & - & - & - \\
\hline Uzbek-Turkmen & 1 & 4.7 & 6.2 & 0.4 & 3.25 & - & 0.2 & - & - & - \\
\hline Transcaucasian & 1.8 & 5.8 & 7.4 & 1.6 & 2.25 & 1.1 & 1.6 & 2.1 & 0.1 & 0.3 \\
\hline Baltic & 8.2 & 6 & 3.8 & 1.6 & 4.85 & 5.2 & 7.6 & 8.5 & 5.45 & 1.8 \\
\hline East European & - & 2.1 & 1 & 4.2 & 6.2 & 0.6 & 2.1 & 2.3 & 2.6 & 0.4 \\
\hline West European & - & 1.6 & 3.3 & 13.2 & 18.9 & 0.3 & 1.2 & 0.6 & 0.7 & 0.3 \\
\hline North European & 0.3 & 1.5 & 1.1 & 4.2 & 3.5 & - & 0.1 & 1 & 2 & 4.5 \\
\hline South European & - & - & 0.2 & 2.1 & 7.15 & - & - & - & - & - \\
\hline Rest of the world & - & - & 0.3 & 0.8 & 4.9 & - & - & - & - & - \\
\hline $\mathrm{K}_{\mathrm{o}}$ & 53.1 & 137.8 & 139.7 & 67.7 & 178.35 & 64.7 & 98.35 & 122.6 & 110.44 & 97.55 \\
\hline
\end{tabular}

Source: own elaboration.

In-Russian spatial structure of air communications to the middle of the second decade of the 21st century finally took the centralized form. A quarter of all flights which are taking off weekly from Pulkovo Airport connect St. Petersburg with the capital region. The communication with nine areas in PostSoviet time has improved, with ten areas it worsened; in a case with one allocated unit the stable state is traced. The greatest dynamics is characteristic of communication with the Upper Volga, Central and Kaliningrad districts. The situation with Upper Volga can be justified by almost total absence of through traffic in 1991 and its existence with four largest settlements of the area in 2016, some of their airports (Vladimir, Kostroma) of $100 \%$ of passenger having contacts with Pulkovo only. The communication with Kaliningrad was strengthened for $253 \%$ in connection with its isolation in Post-Soviet time from the main part of Russia by overland borders. The increase in $\mathrm{C}_{\mathrm{TC}}$ of the Center was record-breaking 33.9 units. The average level of dynamics is characteristic of three east areas - West Siberian, East Ural and Kuznetsk-Altai.
Rise of the significant amount of units of coefficient is registered in the case of the Azovo-Chernomorsky direction.

Air traffic with all areas of Eastern Siberia and the Far East, except Yakut underwent the greatest degradation from the level of 1991. In percentage terms the most catastrophic situation developed in the case of the North of the Far East. Indexes of $C_{T C}$ of the South of the Far East dropped by 1.3 units, of the North and Baikal region - by 1.15 . The greatest recession, for $70.3 \%$, is characteristic of communications with the Lower Volga district. By 2018 raionwide air communications had been completely destroyed, a considerable recession is characteristic also of the Northern area, an indicator of $C_{\mathrm{TC}}$ of which was reduced by 9.3 . Thus, perturbations of the Post-Soviet period most seriously damaged the communications with regions the air traffic of which during the Soviet period was aimed first of all at Leningrad.

In years, preceding the collapse of the USSR, the greatest number of units of aviation coefficient was added in three Soviet areas: East Ukrainian, Trans- 
caucasian and Uzbek-Turkmen. The same districts had maximal absolute measures of $\mathrm{C}_{\mathrm{TC}}$, within two decades indexes on communications with Eastern Ukraine conceded only to the Northern area. The peak of through-air traffic with the Baltics fell on the 1960s then recession of $C_{T C}$ is registered. Sharp rise in the 1970th is characteristic of the communication with Belarus which is due to a large number of transit, recession in the 1980th because of what the difference in an index between 1965 and 1991 turned out slight.

Those areas communication with which had the greatest increase dynamics till 1991 in Post-Soviet time underwent the greatest degradation of indexes. Air traffic with Ukraine was cut after 2015, but decrease in $\mathrm{C}_{\mathrm{TC}}$ was catastrophic even earlier. Reduction of $C_{\mathrm{TC}}$ of the Transcaucasian district during 1991-2016 was $69.6 \%$, the number of the airports, related with St.-Petersburg, by its territories was reduced from eight to five. Having reached a minimum in 2009, the index of the area began to grow and as of 2017 positive dynamics is observed. The index of the message with the Uzbek-Turkmen district decreased twice, the structure was reduced slightly - from 10 airports to eight, but the frequency of flights was considerably reduced. Besides, degradation of communications in 1995 concerning the level of 1991 was more than $90 \%$. Thus, the communication with the area at the moment can be called increasing.

The communication with Kazakhstan was reduced by $38.3 \%$, the structure of communications - instead of 11 airports in 1991 as much as possible became simpler, Pulkovo has contacts in 2017 only with two of them. The minimum of $\mathrm{C}_{\mathrm{TC}}$ was reached in 2009, therefore, in the second decade of the 21st century an increase is characteristic also of air traffic with Kazakhstan. A state close to stagnation is inherent for the St. Petersburg-Chisinau line. If in 1993-2010 C $\mathrm{TC}_{\mathrm{C}}$ of the communication with Kyrgyzstan and Tajikistan decreased to a minimum (0.4), then the increase of an index for $2010-2016$ was $85 \%$. The communication with two nearby districts, Baltic and Belarusian, by 1991 had been considerably reduced in relation to maximum indicators of the Soviet period therefore the $\mathrm{C}_{\mathrm{TC}}$ dynamics in 1991-2016 had bigger percent, than those of communications with other republics. Air traffic with the Crimea which by 2009 was broken completely off is allocated, but after the events of 2014 and railway blockade of the peninsula $C_{\mathrm{TC}}$ grew by $97.7 \%$.

Before "restructuring" ("perestroika") the international communication of Pulkovo Airport had functioned on a considerable scale, however, was affordable for a limited circle of the Soviet citizens and foreign guests. As of 1985 there were five airlines which were mainly connecting with the capital airports of the Northern region of Europe, thirteen communications with the airports of Western Europe (six - with German, the others - with Amsterdam, Vienna, Paris, Luxembourg, London, Zurich and Shannon). Flights to the capitals of the Comecon countries and the Bulgarian resorts were regularly served, flights to Athens were made once a week.

From the first half of the 1990s the Western European directions had become for Pulkovo the second most important after the communication with Moscow, the increase of $\mathrm{C}_{\mathrm{TC}}$ of Western Europe in four Post-Soviet years was 10 units. Strengthening of the communication happened before crisis of 2009 after which the increase slowed down, in 2016 the number of the Western European airports bound to Pulkovo remained invariable in spite of the fact that the index of $C_{T C}$ reached a maximum due to increase in intensity of flights.

The greatest dynamics of foreign communications of Pulkovo Airport in 1995-2016 is characteristic of communications with the southern part of Europe: for this period of $\mathrm{C}_{\mathrm{TC}}$ increased by $240 \%$, body height of an index continues, the number of the airports, related with Pulkovo, constantly changes. If in 1995 $\mathrm{C}_{\mathrm{TC}}$ of Eastern Europe was surpassed by a similar index of the South twice, then by 2016 the last advances the East by coefficient unit. Degradation was characteristic of communications with the countries of the former socialist block in 1995-2009, body height was outlined in the second decade of the 21st century, in 2016 concerning indexes of twenty-year prescription the $C_{\mathrm{TC}}$ value is higher only for $47 \%$. Communication of Pulkovo with Northern Europe in 2016 had the negative dynamics; the communication peak with the area was noted in 2009, after renewing of flights in $2017 \mathrm{C}_{\mathrm{TC}}$ is in Oslo at the level of 1995.

After 1990 there were most extended airlines with New York and Tokyo, the Israeli airline adjusted the communication with Tel Aviv. By 2009 the vector of non-European communications of Pulkovo had been displaced to China, Dubai, Cyprus, North Africa, the communication with Israel remained. Contacts with Cyprus (Larnaca, Monastir) and North Africa (Hurghada, Sharm el-Sheikh) began to have charter character more often. After the start of the new terminal of Pulkovo Airport in 2013 the number of contacts with China - Beijing, Lanzhou, Urumqi, Shanghai, Chengdu increased. By 2018 the communication with Seoul and Qatar had appeared. $C_{\mathrm{TC}}$ of non-European communications grew from 0.3 in 1991 to 4.9 in 2016, a share from $\mathrm{C}_{\mathrm{g}}$ - from $0.2 \%$ to $2.7 \%$.

Passenger rail transportation in Soviet period was carried out generally on small and average distances. During all considered period the leading role 
in internal Leningrad railway passenger communications was played by the message with the Center as the overwhelming majority of the Leningrad trains plied to Moscow, or structures dispersed to different regions on the branch lines which are on the territory of the Central district. The Northern area having a large number of terminal railway points and transit through the Vologda region had a high share. The conciseness of railway communications shows also high percent of nearby Upper Volga district. Central Chernozem and Volga-Vyatka districts had larger transit significance, as important finishing points were the Azovo-Chernomorsky area in the south, and East Ural in the east. The share of other transport regions of RSFSR in structure of railway passenger communications of Leningrad was slight.

Till 1991 the geography of railway passenger communications of Leningrad on the territory of RSFSR considerably extended, trains began to contact to the Lower Volga, Middle Volga, Yenisei and Baikal districts. Communications with the Center and the North, despite the significant superiority over other areas, became stronger even more considerably. The $\mathrm{C}_{\mathrm{TC}}$ of the Upper Volga, Azovo-Chernomorsky and Central Chernozem districts grew by more than three units. The communication with the East Ural district and Kaliningrad stagnated. In four Post-Soviet years in-Russian railway communications were reduced not so considerably as aviation, however, compression of spatial structure of communication still happened. First of all it concerned the southern areas - North Caucasian, Azovo-Chernomorsky, Central Chernozem and Lower Volga that is bound to the reduced communications with the Ukraine, Transcaucasia, instability in the North Caucasus and unprofitability of the Russian resorts. Through summer traffic to the Yenisei and Baikal districts was interrupted. Taking into account the formation of the borders the communication with Kaliningrad weakened twice. The percentage from $\mathrm{Cg}$ the majority of regions of the European part of Russia grew. The largest growth was shown by the short-range communications which reached a maximum in 1995 that also demonstrates spatial compression. In the 1990s there was a decrease in level of compendency to the Central district, however, in fourteen years $C_{\mathrm{TC}}$ exceeded the maximum level of the Soviet period that is due to the beginning of usage of high-speed trains in 2009. The number of communications with the capital grows while stagnation is characteristic of transit through the capital and the general railway coefficient of St. Petersburg that testifies to concentration of railway communication in the Moscow region.

The communication with the Northern district reached its maximum in the first half of the 1990s that is bound to reorientation of passengers to cheaper railway transport and closing of a number of the airports. In the 21st century a compendency with the area decreased and is at the level of the beginning of the 1980th. On a joint of centuries the transit share as the number of the passengers making a trip immediately to settlements of the area decreased increased. Considering the start of high-speed trains "Lastochka" positive shifts of coefficient were outlined. With disappearance of "Iron Curtain", emergence of the recreational competition and deterioration in infrastructure, also $\mathrm{C}_{\mathrm{TC}}$ of the Azovo-Chernomorsky area decreased. Improvement of infrastructure in the venue of the Olympic Games returned the communication with the area to the Soviet indexes. Within 25 years of contemporary history positive dynamics is noted in case of seven districts. Most significant increase in $\mathrm{C}_{\mathrm{TC}}$ is characteristic of districts of Western Siberia after start of trains to Tyumen and Novokuznetsk with hook-on cars. Areas with high dynamics of $C_{T C}$ include West Ural and Middle Volga that is bound to emergence of several trains allowing St. Petersburg to contact directly to Kazan, Samara, Ufa and Izhevsk at once. The volume of the St. Petersburg transit through Perm increased considerably. Growth by $48.6 \%$ of $C_{\mathrm{TC}}$ of the Volga-Vyatka district also depends directly on these areas.

Degradation of the communication is characteristic of nine areas. Besides the fact that running of the summer train to Irkutsk stopped and the land communication with Kaliningrad became complicated, in the 2000s the raion-wide communication degraded. As well as in the case with air traffic, the average level of decrease corresponds with the change of communications with the Northern area. The communication coefficient with Central Chernozem and North Caucasian areas has decreased on a quarter. The general railway coefficient of St. Petersburg decreased by 20.4\% for the period from 1991 to 2016.

Till 1991 indexes of railway communication of Leningrad with all areas, external for RSFSR, had positive dynamics, the strongest links were short-range - with the Baltics and Belarus. The highest level of railway $\mathrm{C}_{\mathrm{TC}}$ among outer areas by the time of disintegration of the Soviet Union was characteristic of the East of the Ukraine. The value of Transcaucasia and Central Asia in structure of railway communications was several times lower than value in aviation structure. The communication with Eastern Europe was carried out by means of through-cars, and was affordable for a limited circle of people.

After 1991 the dynamics of railway $C_{\mathrm{TC}}$ on external areas went downwards. Concerning the political events by 2017 there was a bond breaking to the Crimea, the communication with the two regions of 
the Ukraine decreased to a critical minimum. Through traffic to the Central Asian republics started being carried out only by means of the air transportation, the communication with the Transcaucasian district being represented by only one summer train to Sukhum. Bus transportations and mass emergence of private motor transport made unprofitable railway communication with Estonia and Latvia that lowered communication coefficient with the Baltics by $79 \%$. Taking into consideration the "open borders" mode $\mathrm{C}_{\mathrm{TC}}$ of Belarus decreased to a smaller extent - by $34 \%$. The system of transportation by through-cars to Europe was completely destroyed because of unprofitability. The only external railway direction which developed after falling of "Iron Curtain" is the Finnish one, the start of the high-speed trains "Allegro" increased the communication coefficient several times. However, the growth of the communication with the neighboring state has more political than economic value.

\section{Conclusions}

In the geography of transport there are two main directions of researches - "geography of lines" and "geography of communication". The geography of lines stands for studying of transport infrastructure, while geography of communication is responsible for the studying of cargo and passengers transfer. The transport and geographical location is defined mainly by geography of communications which changes much quicker than geography of lines. The transport and geographical location in the system of freight and passenger traffic differs greatly which is visible on the example of St. Petersburg (in Soviet period of Leningrad). For freight traffics the city is the transport hub where there is an exchange of freights between different types of transport. For passenger traffics St. Petersburg is the deadlock direction, transit passenger traffics on the air transportation are small, on railway transport there are hardly any.

Concerning the fact that the methodology of researches of passenger transport and geographical location is developed insufficiently, the authors suggest their own technique. In the system of passenger traffics it is offered to apply the coefficient of transport compendency (CTC) characterizing the frequency of passenger traffics with the transport and geographical regions of Russia and the foreign countries to a research of transformation of a transport and geographical location of St. Petersburg.

Application of this technique to the analysis of position of St. Petersburg in the system of passenger aviation traffics allowed establishing that throughout Soviet period the city "was displaced" to the North and the East. The value of northern and eastern regions of Russia grew in connection with the general shift of economy and the population of the country to the East at that time. In Post-Soviet time the transport and geographical location of St. Petersburg began to move to the west. The value of northern and eastern directions sharply decreased, while that of western directions (both concerning Russia, and concerning foreign Europe) sharply grew.

The transport and geographical location in the system of rail passenger traffic changed in a slightly different way. Expansion of the sphere of immediate railway passenger inclination of Leningrad of that time was a top trend of Soviet period - passenger trains from Leningrad reached Eastern Siberia, Central Asia and Transcaucasia. In Post-Soviet time, firstly, the number of passenger trains was reduced, secondly, the number of the cities to which trains from St. Petersburg go decreased. In general, as well as in air transportation, the city "drifts" to the West, but the present system of its railway passenger communications is presented mainly by the communication with the cities located in the European part of the Russian Federation. Passenger traffic with the former republics of the USSR was considerably reduced, communication with Eastern and Western Europe stopped, the only city of Northern Europe where the trains go from St. Petersburg is Helsinki, but this communication is supported generally for political reasons.

\section{References}

Baranskiy N.N., 1980. Stanovlenie sovetskoj ehkonomicheskoj geografii [The formation of Soviet economic geography]. Moscow: Mysl' [in Russian].

Bezrukov L. A., Dashpilov C.B., 2010. Transportno-geograficheskoe polozhenie mikroregionov Sibiri: metodika i rezul'taty ocenki [The transport and geographical situation of the micro-regions of Siberia: methods and results of the evaluation], Geography and natural resources, 4, 5-13 [in Russian].

Bugaev V. K. 2007. Socialno-ehkonomicheskaya regionalistika [Socio-economic regionalism]. St. Petersburg: VVM [in Russian].

Bugromenko V. N., 1981. Ekonomicheskaya ocenka transportno-geograficheskogo polozheniya narodnohozyajstvennyh ob'ektov [Economic evaluation of a transport geographical location of economic objects], News of the USSR Academy of Sciences. 5, 66-79 [in Russian].

Bugromenko V. N., 1987. Transport v territorialnyh sistemah [Transport in territorial systems]. Moscow: Nauka [in Russian].

Bulaev V. M., Novikov A. N., 2002. Geograficheskoe polozhenie kak predmet issledovaniya konkretnoy territorii [Geo- 
graphical position as a subject of study of a specific territory]. Ulan-Ude: SB The Russian Academy of Sciences [in Russian].

Fomin G. V., 1990. Raspisanie dvizheniya passazhirskix poezdov na 1991 god [Timetable passenger trains for 1991]. Moscow: Transport [in Russian].

Fomin G. V., 1995. Raspisanie dvizheniya passazhirskix poezdov [Timetable passenger trains]. Moscow: Transport [in Russian].

Kostromin A. V., 2009. Raspisanie dvizheniya passazhirskix poezdov [Timetable passenger trains]. Moscow: Russian Railways [in Russian].

Poster 1965. Timetable of planes from Leningrad Airport in 1965 [in Russian].

Poster 1985. Timetable of planes from Leningrad Airport in 1985 [in Russian].

Poster 1991. Air traffic timetable from the Pulkovo Airport in 1991 [in Russian].

Air traffic timetable from the Pulkovo Airport in 1995 [in Russian].

Tarkhov S. A., 2015. Izmenenie svyaznosti prostranstva Rossii (na primere aviapassazhirskogo soobshcheniya) [Spatial connectivity of Russia: air passenger's flow's case]. Moscow, Smolensk: Oecumene [in Russian].

Tarkhov S. A., 2013. Transport-geographical position. Socialno-ehkonomicheskaya geografiya: ponyatiya i terminy [in Russian].

Taulin B. A., 1962. Raspisanie dvizheniya passazhirskix poezdov na 1962 god [Timetable passenger trains for 1962]. Moscow: Transzheldorizdat [in Russian].

Topchiev A. G., 1974. Formalizovannyj analiz i ocenka transportno-geograficheskogo polozheniya gorodov [A formal analysis and evaluation of transport-geographical position of the cities], Vestnik of Moscow State University, 5 (4), 47-54 [in Russian].

http://www.pulkovoairport.ru/flights/schedule/ - Pulkovo airport schedule

http://rzd.ru/ - Russian Railways official website 